\title{
TRANSFEMINICIDIO: O ASSINATO DE MULHERES TRANS NO BRASIL
}

\section{LUÍSA FONSECA LEMOS MAGALHÃES}

Graduanda em Direito, modalidade integral, pela Escola Superior Dom Helder Câmara. Belo Horizonte- MG. E-mail: luisaflmagalhaes@gmail.com.

CAIO AUGUSTO SOUZA LARA

Mestre e Doutor em Direito pela Faculdade de Direito da Universidade Federal de Minas Gerais - UFMG. Professor da Escola Superior Dom Helder Câmara. Pesquisador Associado ao Programa RECAJ-UFMG - Acesso à Justiça e Solução de Conflitos. Secretário de Comunicação do Conselho Nacional de Pesquisa e Pósgraduação em Direito - CONPEDI. Belo Horizonte-MG. E-mail: caiolarabh@yahoo.com.br.

\section{RESUMO}

O tema-problema da pesquisa que se pretende desenvolver é o assassinato das mulheres transexuais e travestis no Brasil. O transfeminicidio é uma manifestação desse preconceito e ódio tendo como consequência a morte dessas mulheres. De acordo com a doutora em Sociologia, professora da UnB e pós-doutora pela CUNY/EUA Berenice Bento (2014), "o transfeminicídio se caracteriza como uma política disseminada, internacional e sistemática de eliminação da população trans no Brasil, motivada pelo ódio e nojo". E mesmo com as inúmeras mortes no Brasil não há nem uma fonte institucional com esses dados, o que há é o acompanhamento de algumas ONGs de ativistas que acompanham matérias jornalísticas sobre a morte dessas pessoas. Bento, ainda sobre $o$ assunto, ressalta que as pessoas trans passam por dificuldades para serem reconhecidas desde a infância até a morte. De acordo 


\section{Personalidade Acadêmica Homenageada:}

Raymundo Juliano Feitosa (Universidade Federal do Rio Grande do Norte - UFRN)

com ela, durante a infância as pessoas trans já são executadas: "quando as famílias descobrem que o filho ou a filha está se rebelando contra sua natureza e que desejam usar roupas e brinquedos que não são apropriados para o seu gênero, o caminho usado para 'concerta-lo' é a violência." Mesmo depois de morrer o seu gênero é tirado de si e mesmo os ativistas não enfatizam o genero ao fazerem a contabilidade dos mortos (BENTO, 2014). Entre os anos de 2008 e 2016, ocorreram 868 mortes de travestis e transexuais, o maior número de mortes no mundo e esses assustadores números só contribuem para o também assustador dado da baixa expectativa de vida das pessoas trans que de acordo com dados de 2018 era de 35 anos, enquanto a média da população era de 75 anos (THOMAS, 2018). Esse senário que não é único do Brasil reflete o preconceito, ódio, a marginalização e a desumanização dessa população no mundo, mas principalmente no Brasil que deixa essa população vulnerável causando assim esse elevado número de mortes e baixa expectativa de vida. O problema objeto da investigação científica proposta é: como superar os desafios de reduzir a violência, a criminalidade e o assassinato em função da identidade de gênero? A partir das reflexões preliminares sobre o tema, é possível afirmar inicialmente que a população trans está em situação vulnerável devido ao grande preconceito a população LGBT, especialmente trans, presente na sociedade atual incluindo a e principalmente a brasileira. Devido a isso, o mundo tem um alto número de casos de violência e assassinato contra a população trans no mundo. E o Brasil é o país com o maior número desses assassinatos no mundo. O objetivo geral desse trabalho é analisar os assassinatos de mulheres trans no Brasil e sua relação com o preconceito com a população trans e com a população LGBT como um todo, além de verificar a transformação deste preconceito em ódio. A pesquisa que se propõe pertence à vertente metodológica jurídico-sociológica. No tocante ao tipo de investigação, foi escolhido, na classificação de Witker (1985) e Gustin (2010), o tipo jurídico-projetivo. $O$ raciocínio desenvolvido na pesquisa será predominantemente dialético. De acordo com a técnica de análise de conteúdo, afirma-se que trata-se de uma pesquisa teórica, o que será possível a partir da análise de conteúdo dos textos doutrinários, normas e demais dados colhidos na pesquisa. Como conclusão parcial do trabalho, tem-se que devido principalmente ao preconceito e ao ódio as mulheres 
Personalidade Acadêmica Homenageada:

Raymundo Juliano Feitosa (Universidade Federal do Rio Grande do Norte - UFRN)

trans são desumanizadas e agredidas sendo muitas vezes assassinadas, desse modo reduzindo a expectativa de vida dessas mulheres que é presente em todo o mundo e enfatizado no Brasil.

PALAVRAS-CHAVE: Transgêneros; Assassinato; Violência; Preconceito.

\section{REFERÊNCIAS}

BENTO, Berenice. Brasil: pais do Transfeminicídio. Centro Latino-Americano em sexualidade e direitos humanos, Rio de Janeiro, 04 jun 2014. Disponível em: http://www.clam.org.br/uploads/arquivo/Transfeminicidio_Berenice_Bento.pdf.

Acesso em: 9 maio 2019.

CAMPOS, Ingrid Zanella Andrade; NETO, Clarindo Empaminondas de Sá. A Cidadania sexual fraterna: Por uma concepção de dignidade para as pessoas "trans" Revista Jurídica - UNICURITIBA, Curitiba, vol. 01 no 50, 2018. Disponivel em: http://revista.unicuritiba.edu.br/index.php/RevJur/article/view/2549/1513. Acesso em: 9 maio 2019.

CAZELATTO, C E C.; CARDIN, V S G. Do Discurso de Ódio Homotransfóbico e o Direito á Vida dos Transgêneros, In: VIEIRA, Tereza Rodrigues (org.). Transgeneros. 1 ed. Brasilia: Zakarewiscz Editora, 2019.

COTRIM, Jonathas. Minas terá a primeira candidata trans ao Senado. O Estado de S Paulo, São Paulo, 12 ago. 2018. Disponível em: https://politica.estadao.com.br/noticias/eleicoes, minas-tera-a-primeira-candidatatrans-ao-senado,70002446673. Acesso em: 9 maio 2019.

CUNHA, Thaís. Brasil lidera ranking mundial de assassinatos de transexuais. Correio Braziliense, Brasília. Disponível em: http://especiais.correiobraziliense.com.br/brasillidera-ranking-mundial-de-assassinatos-de-transexuais. Acesso em: 9 maio 2019.

GUSTIN, Miracy Barbosa de Sousa; DIAS, Maria Tereza Fonseca. (Re)pensando a pesquisa jurídica: teoria e prática. 3ª . ed. Belo Horizonte: Del Rey, 2010.

LEITE, Hellen. Transexual, travesti, drag queen... qual é a diferença? Correio Braziliense, Brasília. Disponível em: http://especiais.correiobraziliense.com.br/transexual-travesti-drag-queen-qual-e-adiferenca. Acesso em: 9 maio 2019. 
Personalidade Acadêmica Homenageada:

Raymundo Juliano Feitosa (Universidade Federal do Rio Grande do Norte - UFRN)

THOMAS, Danilo. Reduzida por homicídios, a expectativa de vida de um transexual no brasil é de apenas 35 anos. Época, 31 jan 2018. Disponivel em: https://epoca.globo.com/brasil/ noticia/2018/01/reduzida-por-homicidios-expectativade-vida-de-um-transexual-no-brasil-e-de-apenas-35-anos.html. Acesso em: 9 maio 2019.

VIEIRA, Tereza Rodrigues (org.). Transgeneros. 1 ed. Brasilia: Zakarewiscz Editora, 2019.

WITKER, Jorge. Como elaborar uma tesis en derecho: pautas metodológicas y técnicas para el estudiante o investigador del derecho. Madrid: Civitas, 1985 